\title{
Students' Assessment of Difficulty and Preferences Regarding L2 Language Skills
}

\author{
Alenka Mikulec \\ Faculty of Teacher Education, University of Zagreb, Croatia \\ alenka.mikulec@ufzg.hr
}

Siniša Subotić

Faculty of Natural Sciences and Mathematics \& Department of Psychology at the Faculty of Philosophy, University of Banja Luka, Bosnia and Herzegovina sinisa.subotic@pmf.unibl.org

\section{Introduction}

Language proficiency is primarily seen as a "multifaceted modality" which consists of various levels of abilities and domains rather than as "a unidimensional construct" (Carrasquillo, 1994, p. 65). Hence, an important aspect of any language acquisition process, both for mother tongue (L1) and foreign (L2) languages, is the development of the four basic language skills: reading, writing, listening and speaking.

Each of these skills has its specific features, especially in the context of foreign or second language learning. Reading and reading comprehension imply successful application of a number of activities such as: visual processing of words; identifying their phonological, orthographic, and semantic representations; using syntactic rules to connect the words; understanding the underlying meaning of words and phrases, etc. (Perfetti \& Stafura, 2014). Moreover, a successful reader needs to integrate the underlying meaning across sentences, employ related background knowledge, make inferences, identify text structure, and consider the authors' motives (Graesser, 2015).

Writing is considered not only "a matter of arranging elements in the best order", but rather "a sociocognitive activity which involves skills in planning and drafting as well as knowledge of language, contexts, and audiences" (Hyland, 2003, pp. 7, 23). Therefore, Hyland (2003, p. 23) proposes the following principal orientations to teaching L2 writing: 1) structure (emphasis is on language form, i.e. grammatical accuracy and vocabulary development), 2) function (focus is on language use in the form of paragraph and text organisation patterns), 3) expressivist (emphasizes writer's individual creativity and selfdiscovery), 4) process (emphasis is on the writer's control of technique), 5) content (focus is on the subject matter), and 6) genre (focus is on the text and context whereby the writer has 
to display control of rhetorical structure of specific text-types). In other words, there are a number of factors which need to be considered when talking about L2 writing.

The next skill is listening, which is, according to Jafari and Hashim (2015), crucial for comprehensible input since more than $50 \%$ of L2 learners' time is dedicated to listening. Rost (2002) has confirmed its importance by pointing out that proficiency in listening is a major precondition for achieving proficiency in speaking. However, although listening comprehension is "at the heart of language learning", it is still "the least understood and least researched skill" (Vandergrift, 2007, p. 191). Thomas and Dyer (2007, as cited in Hamouda, 2013) observed that many teachers associate listening with breathing and consider it to be automatic despite the fact that it implies a number of complex activities on the part of the listener. Namely, it is a process in which a listener receives the information from a speaker, constructs and represents meaning, negotiates meaning with the speaker and responds, until he/she finally creates meaning through involvement, imagination and empathy (Rost, 2002). Therefore, there are a number of listening difficulties L2 learners have reported experiencing: not being able to recognize words, missing the beginning of a sentence or message, inability to understand something because of a lack of understanding of the previous section, concentration problems, quickly forgetting what has been heard, inability to form mental representations from what has been heard, and inability to understand the message despite the understanding of words (Goh, 2000, as cited in Vandergrift \& Goh, 2012). In addition, Vandergrift and Goh (2012) emphasize that listening activities in L2 classrooms usually focus mainly on the outcomes of listening, i.e. they test the learners' listening skills, which consequently only increases their anxiety, especially when they are expected not only to understand what they are listening but also to respond in the appropriate way.

Speaking, as the last (but not least) of the language skills, may be considered both as the most difficult and the easiest of the four skills (Celce-Murcia \& Olshtain, 2000). It is deemed difficult because it "requires command of both listening comprehension and speech production subskills (e.g. vocabulary retrieval, pronunciation, choice of a grammatical pattern, and so forth) in unpredictable, unplanned situations" (Celce-Murcia \& Olshtain, 2000, p. 165). On the other hand, it is viewed as the easiest of the four skills because when communicating with someone, speakers need not rely solely on their language skills as they "can use body language, demonstration, repetition, and various other strategies" (CelceMurcia \& Olshtain, 2000, p. 165). According to Nation (2011), speaking, which is mostly an interactive and a meaning-focused activity, may also be used to help learners expand their language knowledge, i.e. it may facilitate vocabulary development, pronunciation, and gaining control of grammatical and discourse features. Finally, in order for EFL/ESL learners' speaking skills to be developed, emphasis should be on speaking confidence combined with appropriate tasks (Bailey, 2005; Nunan, 2006; Trent, 2009).

All of the above skills are equally important in the context of EFL learning and teaching because of the role the English language has in global communication and 
knowledge exchange in all spheres of human life.

The goal of language teaching is the development of learners' communicative competence, and language skills are considered to be "both the aim and the means for the implementation of the communicative goal" (Frydrychova Klimova, 2014, p. 87). When language teaching is structured so that it integrates all language skills, it enables learners to activate different communicative processes simultaneously, and contributes to the functional language use. Despite many benefits of integrated skill instruction, and the fact that for many years now integration of all four language skills has been emphasized in L2 teaching and learning (Baker \& Westrup, 2003; Byrne, 1984; Oxford, 2001; Šebestova, Najvar, \& Janik, 2011; Selinker \& Tomlin, 1986), there is nevertheless a significant body of work focusing on the development of individual language skills (cf. reading: Grabe (2009), Hudson (2007), Koda (2004); listening: Field (2009), Flowerdew \& Miller (2005), Lynch (2009); speaking: Alonso Alonso (2018), Boxer \& Cohen (2004); and writing: Hyland (2003), Silva \& Matsuda (2001)).

A number of aspects and factors related to language acquisition, e.g., learners' perceived competence, beliefs, attitudes, etc., have been found to significantly impact language learning and teaching process. Therefore, understanding these factors may be considered an important step towards facilitating language acquisition and helping learners to achieve higher language proficiency. One of these factors is learners' perception of language skill difficulty. However, rather contradictory findings have been reported regarding this issue. Namely, an analysis of previous studies, which were mainly conducted with graduate and/or undergraduate students, who were EFL learners, indicates that different language skills have been perceived as the most/least difficult by EFL learners. For instance, Hamouda (2013), and Ishag, Altmayer, and Witruk (2015) reported speech comprehension to have been perceived as the most difficult to learn. On the other hand, Graham (2006) and Kim (2002) found listening as the language skill perceived to be the most difficult. Since in Graham's study (2006) the participants were English students learning French, and Kim's (2002) participants were Korean students taking the TOEFL test, it may be that different mother tongues and foreign languages as well as different learning/testing context may have caused differences in students' perceptions of language skill difficulty. Berman and Cheng (2010) reported listening, in addition to reading, as the least difficult language skills while speaking and writing were considered the most difficult. A possible reason for such a perception of speaking and writing may be that these two productive language skills have been found to be the least developed in ELT among primary and secondary school EFL learners (Mihaljević Djigunović, 2006a; Šebestova, Najvar, \& Janik, 2011). A study conducted by Zergollern-Miletić (2007) showed that Croatian primary and secondary EFL students achieved best results on their reading test, which may be why EFL students tend to perceive reading as the least difficult language skill, as confirmed in a study by Ishag et al. (2015).

In addition to language difficulty, affective domain has also long been identified as 
being very important in L2 learning, both by researchers and educators. One of the factors belonging to this domain are attitudes, i.e. "acquired and relatively durable relationships the learner has to an object" (Mihaljević Djigunović, 2006a, p. 10), which have been assigned an important place in L2 learning, especially attitudes towards different aspects of the teaching situation (cf. Dörnyei, 2001; Nikolov, 2002). Attitudes have also been studied in relation to language skills. So, for instance, Smith (1990, p. 215) defines reading attitude as "a state of mind, accompanied by feelings and emotions that make reading more or less probable". The other language skills may also be described in terms of learners' attitudes towards them.

Despite numerous studies investigating the process of EFL learning and teaching, to our knowledge, there is scarce data regarding the degree to which perceived EFL skills' difficulty is related to corresponding learners' negative attitudes towards them. It has been established that L1 might be associated with stronger emotional connotations (e.g. when expressing love and anger) (Dewaele, 2008, 2010), and that (L2) anxiety tends to be negatively related to several language-related outcomes (e.g. word recollection and production, writing and oral proficiency, etc.) (Dewaele, 2010). Moreover, anxiety in an EFL context has been investigated in relation to EFL learning in general, but also in relation to the four language skills. It has most frequently been associated with the oral aspects of language use (Horwitz, 2001; Mihaljević Djigunović, 2002), but studies have focused on the other language skills as well. For instance, Mihaljević Djigunović and Legac (2008) and Kim (2000) found negative correlation between anxiety and EFL listening achievement. However, a relationship between subjectively perceived difficulty of individual language skills and learners' negative attitudes towards them has not been studied in sufficient detail.

Howe (2002) has emphasized the importance of positive transfer of the existing skills and its effect on the acquisition of new skills and knowledge, but the reverse has also been confirmed, i.e. it was proposed that new information may have a positive impact on understanding previously acquired knowledge (Vizek Vidović et al., 2003). Languages are no exception, that is, Koda (2004) pointed out that L1 knowledge and learning experiences are more than welcome in L2 acquisition, but L2 may also frequently be observed in bilingual speaker's L1 since the two languages are closely interrelated (Cook, 2003; Littlewood, 2004). Consequently, constant interactions and language transfer across languages confirm Cook's (1991) notion of multi-competence as knowledge of more languages in one mind. The possibility of transfer across languages has been investigated by Mihaljević Djigunović (2006b) in a study involving 13-14-year-old Croatian EFL learners. A possible interaction of L1 and L2 language skills (all but L1 speaking) was examined and the results confirmed interlingual interaction between L1 and L2, with the strongest interaction being observed for reading, and somewhat weaker one for listening and writing. 


\section{The Study}

\subsection{Study Aim}

The degree to which subjectively perceived language skills' difficulty is related to corresponding learners' negative attitudes towards them is largely unknown. Thus, the primary objective of this study was to determine the degree to which university EFL learners find a particular L2 skill as being the most/least favourite and the most/least difficult. In addition, we aimed to ascertain how strongly the perceived difficulty is correlated with the learners' subjective dislike of that same language skill.

\subsection{Instrument and Procedure}

The research questionnaire consisted of five open and closed-ended questions (Appendix 1) ${ }^{1}$ used to collect basic information about the participants and their EFL learning history (age, length of EFL learning and EFL proficiency self-assessment). The participants were also asked to assess subjective difficulty and dislike/preference for the following L2 language skills: reading out loud, silent reading, listening, speaking, and writing. Each of the skills was assessed using 5-point Likert-type scales where 1 indicated the most difficult/preferred and 5 indicated the least difficult/preferred language skill, but the ratings were re-coded for the analyses so that higher values indicate higher difficulty and higher preference. The questionnaire, written and completed by the participants in the Croatian language, was administered during regular English for Academic Purposes language classes. Data analyses were done in R software (R Core Team, 2013).

\subsection{Sample}

Research participants were eighty-three female university students (pre-service primary and preschool teachers) whose L1 is Croatian, and L2 English. The students were enrolled in English for Specific Academic Purposes course and their proficiency level, according to the CEFR, was between B1 and B2 while their self-assessed EFL proficiency was 3.64 (out of 5). The participants' mean age was $21.34(S D=1.61)$ years, and the average length of learning EFL was about 10 years $(M=10.17, S D=2.91)$ (Mikulec, 2016).

\section{Results and Discussion}

The obtained results (Table 1) indicate that listening and silent reading were considered the

\footnotetext{
${ }^{1}$ Croatian version of the questionnaire and some of the obtained results, as indicated in the paper, are parts of a larger study which was conducted in the process of $\mathrm{PhD}$ thesis writing by the first author (Mikulec, 2016).
} 
least difficult and the most preferred, while speaking and writing were considered the most difficult and the least preferred language skills. Therefore, it may be proposed that the perceived EFL skills difficulty in this research is in accordance with some earlier findings (Berman \& Cheng, 2010; Hamouda, 2013; Ishag et al., 2015). In addition, Flowerdew, Miller, and $\mathrm{Li}(2000)$ found that EFL learners assessed their listening proficiency as high, which may also be why this skill was perceived as the least difficult and most preferred in the present research.

Since studies (Buben, 2018; Horwitz, 2001; Mihaljević Djigunović, 2002) have suggested that L2 learners usually name speaking as the skill causing most anxiety, it could consequently present a significant obstacle to successful L2 acquisition. This may explain why the participants in the present research also perceived speaking and reading out loud as the more difficult language skills than silent reading and listening.

Table 1 Mean values and standard deviations for the self-assessed difficulty and preferences for the tested language skills

\begin{tabular}{lcc|cc}
\hline Variables & \multicolumn{2}{c|}{ Difficulty } & \multicolumn{2}{c}{ Preferences } \\
& $\boldsymbol{M}$ & $\boldsymbol{S D}$ & $\boldsymbol{M}$ & $\boldsymbol{S D}$ \\
\hline Reading out loud & 2.78 & 1.26 & 2.72 & 1.17 \\
Silent reading & 1.84 & 0.96 & 3.41 & 1.41 \\
\hline Writing & 3.66 & 1.20 & 2.54 & 1.17 \\
Speaking & 3.70 & 1.22 & 2.57 & 1.43 \\
\hline Listening & 2.08 & 1.27 & 3.75 & 1.45 \\
\hline
\end{tabular}

A possible reason why writing was considered the second most difficult skill is that, as mentioned earlier, it encompasses a significant number of micro-skills which, according to Hyland (2003), every successful learner needs to master (grammatical accuracy and vocabulary development, language use, creativity, text organisation, etc.).

Table 2 Correlations between difficulty and preference values

\begin{tabular}{ll}
\hline Difficulty Preferences (pair) correlations & $\boldsymbol{\rho}$ \\
\hline Reading out loud & $-.400^{* * *}$ \\
Silent reading & $-.501^{* * *}$ \\
Writing & $-.287^{* *}$ \\
Speaking & $-.648^{* * *}$ \\
Listening & $-.468^{* * *}$ \\
\hline
\end{tabular}

Notes: ${ }^{* * *} p<.001,{ }^{* *} p<.01$

Correlations between difficulty and preference assessments for each of the language 
skills are shown in Table 2 . The average correlation for the difficulty and preference assessments (for all skills combined) was: $\rho=-.46(S D=0.13)$. The more difficult the skill was perceived to be, the more students disliked it, to a moderate degree, which is not surprising, given an obvious tendency towards disliking things that are perceived as more difficult. However, it is important to note that this also implies that perceived language skill difficulty does not automatically mean high dislike of that skill.

In the next step, we compared all the correlations to one another, in order to establish if any of them were significantly lower or higher than the others. The only significant difference between correlations was obtained for subjective difficulty and preference for the two most difficult skills: writing and speaking: $Z=-3.02, p_{\text {-corrected }}=.03$. It is important to remember that these are the skills almost identically perceived as the most difficult and the most disliked. However, correlation between difficulty and preference was the lowest for writing $(\rho=-.29, p=.009)$, and the highest for speaking $(\rho=-.65, p<.001)$. In other words, although both skills were similarly difficult and disliked, the extent of the learners' dislike for speaking is much more related to its perceived difficulty than is the case with writing.

This finding implies that the processes underlying these language skills and their assessments are probably different, as the difficulty assessment level does not necessarily translate into high dislike of these two skills in the same way. Note that speaking is mainly performed in public, i.e. it is more social, whereas writing is generally seen as an individual activity. It is possible that social situation causes greater anxiety during speaking activity, especially if the subjects are more introverted, as introversion and extraversion are related to low or high tendency (respectively) of finding pleasure in different social contexts, interpersonal communication, etc. (John \& Srivastava, 1999), and introverts are more prone to language anxiety (Brown, Robson, \& Rosenkjar, 2001). Therefore, students' introversion may lead to stronger relationship between the self-perceived difficulty and dislike of this language skill. Furthermore, due to known negative association between the (L2) anxiety and language proficiency measures (Dewaele, 2010; Horwitz, 2001; Kim, 2000; Mihaljević Djigunović \& Legac, 2008), it is possible that anxiety both moderates and directly influences the relationship between subjective difficulty and dislike assessments of L2 skills. However, at this point, this is merely a tentative hypothesis.

Another aspect to consider is the similarity between the L1 and L2 pattern of correlations. In other words, it would be interesting to see if the effects might replicate for L1, especially since studies have confirmed positive interlingual interaction between L1 and L2 skills (Mihaljević Djigunović, 2006b). Assuming that students are literate in L1, their attitudes towards the native language have been found to represent a source of attitudes toward L2 reading (Day \& Bamford, 1998, p. 23). The students who feel more anxious in L1 reading are probably going to feel more anxious in L2 reading as well (Yamashita, 2007). Thus, examining the differences and similarities in both L1 and L2 language skills' difficulty and preference assessments in relation to personality and setting factors should be considered in further research. 


\section{Limitations of the Study}

Although the study provided novel insights into learners' difficulty and preference assessment of EFL learning skills, there are certain limitations that need to be considered. Firstly, the sample of participants was a relatively small, gender-homogenous convenience sample, and therefore the transferability of the obtained results is limited. Another limitation refers to the fact that the results were obtained through participants' self-reports, which greatly relied on the participants' honesty, but even more so on their introspective ability to provide honest and accurate answers. Also, certain important affective factors (i.e. motivation, anxiety, and general personality, namely extraversion), as well as the quality of teaching and teachers' skill preferences, which would have provided valuable insight into the matter, have not been measured. Finally, the rating of the difficulty and preference for specific language skills did not take into account all of their possible variations pertaining to the context in which the activities related to particular skills take place, namely, speaking in class, in the street with a foreigner, or with a native speaker.

\section{Conclusion}

The results of the present study indicate that, since the average correlation between L2 language skills' difficulty and preference assessments was found to be moderate, the difficulty assessment level need not automatically translate into high dislike. This means that other (perhaps personality and/or situational) factors might be important to consider, especially since the largest difference in correlations was observed for two of the most difficult skills as perceived by the participants, i.e., speaking and writing. This is considered a novel finding and implies that the processes underlying these assessments are probably different and need to be further investigated.

\section{Suggestions for Further Research}

The observed difference in the strength of associations between subjective difficulty and preference ratings for writing and speaking is a novel finding, which (to our knowledge) has not been previously tested. We suggest that the best course of action is to investigate whether or not personality (mainly extraversion and anxiety) indeed moderates these correlations. Another thing to consider is to experimentally manipulate the context and the manner in which the language related activities take place - e.g. writing in a notebook as opposed to writing on the blackboard (in front of other students); speaking before a group of students during a whole-class discussion versus speaking with only one person; teachers' preference and more significant focus on developing some language skill(s) more than 
others, etc. In general, we suggest that personality and individual differences, as well as the actual setting in which the language activities take place are the factors to be taken into consideration in follow-up studies.

\section{References}

Alonso Alonso, R. (Ed.) (2018). Speaking in a Second Language (AILA Applied Linguistics Series, vol. 17). Amsterdam: John Benjamins Publishers.

Bailey, K. M. (2005). Practical English Language Teaching: Speaking. New York: McGraw-Hill. Baker, J., \& Westrup, H. (2003). Essential Speaking Skills: A Handbook for English Language Teachers. London: Continuum.

Berman, R., \& Cheng, L. (2010). English academic language skills: Perceived difficulties by undergraduate and graduate students, and their academic achievement. Canadian Journal of Applied Linguistics/Revue canadienne de linguistique appliquée, 4(1), 25-40.

Boxer, D., \& Cohen, A. D. (Eds.) (2004). Studying Speaking to Inform Second Language Learning. Clevedon, Buffalo, Toronto: Multilingual Matters.

Brown, J. D., Robson, G., \& Rosenkjar, P. R. (2001). Personality, motivation, anxiety, strategies, and language proficiency of Japanese students. In Z. Dornyei, \& R. W. Schmidt (Eds.), Motivation and second language acquisition (pp. 361-398). Honolulu: University of Hawaii, Second Language Teaching and Curriculum Center.

Buben, K. (2018). Listening and Speaking Anxiety in Croatian EFL Learners. (Unpublished graduation thesis). Zagreb: Faculty of Humanities and Social Sciences, Department of English, University of Zagreb.

Byrne, D. (1984). Integrating Skills. In K. Johnson, \& K. Morrow (Eds.), Communication in the Classroom. Applications and Methods for the Communicative Approach (pp. 108-114). London: Longman.

Carrasquillo, A. L. (1994). Teaching English as a second language: A resource guide. New York: Garland Publishing.

Celce-Murcia, M., \& Olshtain, E. (2000). Discourse and Context in Language Teaching. Cambridge: Cambridge University Press.

Cook, V. (1991). The poverty-of-the-stimulus argument and multicompetence. Second Language Research, 7(2), 103-117.

Cook, V. (Ed.) (2003). Effects of the Second Language on the First. Clevedon: Multilingual Matters Ltd.

Day, R., \& Bamford, J. (1998). Extensive reading in the second language classroom. Cambridge: Cambridge University Press.

Dewaele, J. (2008). The emotional weight of "I love you" in multilinguals' languages. Journal of Pragmatics, 40(10), 1753-1780.

Dewaele, J. (2010). Emotions in multiple languages. UK: Palgrave Macmillan. 
Dörnyei, Z. (2001). Teaching and researching motivation. London: Longman.

Field, J. (2009). Listening in the Language Classroom. Cambridge: Cambridge University Press. Flowerdew, J., \& Miller, L. (2005). Second Language Listening: Theory and Practice. Cambridge: Cambridge University Press.

Flowerdew, J., Miller, L., \& Li, D. S. C. (2000). Chinese lecturers' perceptions, problems and strategies in lecturing in English to Chinese-speaking students. RELC, 31, 116-138.

Frydrychova Klimova, B. (2014). Detecting the development of language skills in current English language teaching in the Czech Republic. Procedia - Social and Behavioral Sciences, 158, 85-92.

Geoghegan, G. (1983). Non-native speakers of English at Cambridge University: linguistic difficulties and social adjustment. Cambridge: Bell Educational Trust.

Goh, C. (2000). A cognitive perspective on language learners' listening comprehension problems. System, 28, 55-75.

Grabe, W. (2009). Reading in a Second Language: moving from theory to practice. Cambridge: Cambridge University Press.

Graesser, A. C. (2015). Deeper learning with advances in discourse science and technology. Policy Insights from the Behavioral and Brain Sciences, 2, 42-50.

Graham, S. (2006). Listening comprehension: The learners' perspective. System, 34, 165-182. Hamouda, A. (2013). An Investigation of Listening Comprehension Problems Encountered by Saudi Students in the EL Listening Classroom. International Journal of Academic Research in Progressive Education and Development, 2(2), 113-155.

Horwitz, E. K. (2001). Language Anxiety and Achievement. Annual Review of Applied Linguistics, 21, 112-126.

Howe, M. J. A. (2002). Psihologija učenja. Jastrebarsko: Naklada Slap.

Hudson, T. (2007). Teaching Second Language Reading. Oxford: Oxford University Press. Hyland, K. (2003). Second Language Writing. New York. Cambridge University Press.

Ishag, A., Altmayer, C., \& Witruk, E. (2015). A comparative self-assessment of difficulty in learning English and German among Sudanese students. Journal of Language and Cultural Education, 3(2), 32-38.

Jafari, K., \& Hashim, F. (2015). Comparison of Normal and Moderately Slow Speech Rates: Listening to Students' Voices in Listening Comprehension Classes in EFL Context. International Journal of Foreign Language Teaching in the Islamic World, 3(3), 5-11.

John, O. P., \& Srivastava, S. (1999). The Big-Five trait taxonomy: History, measurement, and theoretical perspectives. In L. A. Pervin \& O. P. John (Eds.), Handbook of personality: Theory and research (Vol. 2) (pp. 102-138). New York: Guilford Press.

Jordan, R. R. (1997). English for Academic Purposes: A Guide and Resource Book for Teachers. Cambridge: Cambridge University Press.

Kim, J.-H. (2000). Foreign language listening anxiety: A study of Korean students learning English. Unpublished doctoral dissertation, The University of Texas, Austin.

Kim, J-H. (2002). Affective reactions to foreign language listening retrospective interviews 
with Korean EFL students. Language Research, 38, 117-151.

Koda, K. (2004). Insights into second language reading: A Cross-Linguistic Approach. Cambridge: Cambridge University Press.

Littlewood, W. (2004). Second Language Learning. In A. Davies, \& C. Elder (Eds.), The Handbook of Applied Linguistics (pp. 501-524). Oxford, UK: Blackwell Publishing Ltd.

Lynch, T. (2009). Teaching Second Language Listening: A guide to evaluating, adapting, and creating tasks for listening in the language classroom. Oxford: Oxford University Press.

Mihaljević Djigunović, J. (2002). Strah od stranoga jezika. Zagreb: Naklada Ljevak.

Mihaljević Djigunović, J. (2006a). Role of affective factors in the development of productive skills. In M. Nikolov, \& J. Horvath (Eds.), UPRT 2006: Empirical studies in English applied linguistics (pp. 9-23). Pecs: Lingua Franca Csoport.

Mihaljević Djigunović, J. (2006b). Interaction between L1 and L2 communicative language competences. SRAZ, 50, 261-277.

Mihaljević Djigunović, J., \& Legac, V. (2008). Foreign Language Anxiety and Listening Comprehension of Monolingual and Bilingual EFL Learners. SRAZ, LIII, 327-347.

Mikulec, A. (2016). Strategije čitanja akademskih tekstova na hrvatskome i engleskome jeziku. (Unpublished doctoral dissertation). Zagreb: Faculty of Humanities and Social Sciences, University of Zagreb.

Nation, I. S. P. (2011). Second language speaking. In E. Hinkel (Ed.), Handbook of Research in Second Language Teaching and Learning. Volume 2, Chapter 27 (pp. 444-454). New York: Routledge.

Nation, I. S. P., \& Newton, J. (2009). Teaching ESL/EFL Listening and Speaking. New York and London: Routledge.

Nikolov, M. (2002). Issues in English language education. Bern: Peter Lang.

Nunan, D. (2006). Task-based language teaching in the Asia context: Defining 'task'. Asian EFL Journal, 8(3), 12-18.

Oxford, R. (2001). Integrated Skills in the ESL/EFL Classroom. ERIC Digest. Retrieved from https://files.eric.ed.gov/fulltext/ED456670.pdf

Perfetti, C., \& Stafura, J. (2014). Word knowledge in a theory of reading comprehension. Scientific Studies of Reading, 18, 22-37.

$R$ Core Team (2013). R: A language and environment for statistical computing. R Foundation for Statistical Computing, Vienna, Austria. Retrieved from http://www.R-project.org/

Rost, M. (2002). Teaching and Researching Listening. London, UK: Longman.

Selinker, L., \& Tomlin, R. S. (1986). An empirical look at the integration and separation of skills in ELT. ELTJ, 40(3), 227-235.

Silva, T., \& Matsuda, P. K. (Eds.) (2001). On Second Language Writing. Mahwah, NJ: Lawrence Erlbaum Associates.

Smith, M. C. (1990). A longitudinal investigation of reading attitude development from childhood to adulthood. Journal of Educational Research, 83(4), 215-219.

Šebestova, S., Najvar, P., \& Janik, T. (2011). Příležitosti k rozvíjení řečových dovedností ve 
výuce anglického jazyka: samostatně anebo v integraci. Pedagogicka orientace, 21(3), 322-348.

Thomas, I., \& Dyer, B. (2007). The Problem of Poor Listening Skills. Retrieved from faculty.weber.edu/.

Trent, J. (2009). Enhancing oral participation across the curriculum: Some lessons from the EAP classroom. Asian EFL Journal, 11(1), 256-270.

Vandergrift, L. (2007). Recent developments in second and foreign language listening comprehension research. Language Teaching, 40, 191-210.

Vandergrift, L., \& Goh, C. C. M. (2012). Teaching and Learning Second Language Listening: Metacognition in Action. New York: Routledge.

Vizek Vidović, V., Rijavec, M., Vlahović-Štetić, V., \& Miljković, D. (2003). Psihologija obrazovanja. Zagreb: IEP.

Yamashita, J. (2007). The relationship of reading attitudes between L1 and L2: An investigation of adult EFL learners in Japan. TESOL Quarterly, 41(1), 81-105.

Zergollern-Miletić, L. (2007). Ovladanost vještinom pisanja na engleskome jeziku na kraju osnovnoškolskog i srednjoškolskog obrazovanja kod hrvatskih učenika. Metodika, 8(1), 190-204.

\section{Appendix: Questionnaire}

\section{Background Data}

1. Age

2. How long have you been learning English?

3. On a scale 1-5 (1 - very low, 5 - excellent) grade your English language proficiency.

\section{Language activities - difficulty and preference}

4. Grade the following activities in your English language class according to the level of perceived difficulty (on a scale $1-5$, where 1 is the most difficult, and 5 the least difficult activity)?
a. reading aloud
b. silent reading
c. writing
d. speaking
e. listening

5. Grade the following activities in your English language class according to the level of perceived preference (on a scale 1-5, where 1 is the most favourite and 5 the least 
favourite activity)?
a. reading aloud
b. silent reading
c. writing
d. speaking
e. listening 